\title{
Op afstand dichtbij
}

\section{Twee jonge zorgprofessionals over hun ervaringen in coronatijd}

Begin juni, aan de vooravond van de versoepeling van de bezoekregeling in de verpleeghuizen, sprak journalist Dieuwke de Boer met casemanager Lies Orthmann en verpleegkundige Teun Toebes. De coronacrisis is ook deze twee bevlogen zorgprofessionals en Denkbeeldredacteuren niet in de koude kleren gaan zitten. Hoe hebben zij de bezoekstop en de andere beperkingen ervaren? En zijn er ook positieve lessen te trekken voor de toekomst?

$\mathrm{H}$ oewel het op slechts twintig kilometer van het epicentrum van de uitbraak lag, wist het Brabantse verpleeghuis waar Teun werkt het virus buiten de deur te houden. 'Na de aankondiging van de eerste maatregelen wisten we nog niet goed wat we moesten verwachten, maar toen het bezoekverbod werd afgekondigd hakte dat er bij iedereen flink in,' zegt hij. Voor Lies betekende het dat ze alleen nog de meest urgente huisbezoeken kon afleggen; de rest probeerde ze via telefoon of beeldbellen te regelen. Lies: 'Persoonlijk contact is een ontzettend belangrijk en noodzakelijk aspect van werken met mensen met dementie en hun mantelzorgers. Juist dat viel van de ene op de andere dag helemaal weg of werd zwaar beperkt. Ik kon veel regelen via de telefoon, maar realiseerde me direct hoe belangrijk non-verbale communicatie eigenlijk is. Tijdens gesprekken kijk ik altijd naar iemands gezichtsuitdrukking om te checken of ik op het goede spoor zit. En zo nodig ga ik geknield naast iemand zitten of leg ik ter geruststelling even een hand op iemands arm. Ik stem veel van mijn communicatie dus af op wat ik zie, maar andersom probeer ik ook met mijn eigen gezichtsuitdrukkingen vertrouwen te geven of mijn verhaal kracht bij te zetten.'

Teun: 'Juist mensen met dementie krijgen een steeds grotere behoefte aan lichamelijk contact omdat taal verdwijnt. Maar wij kunnen als hulpverleners de familie niet vervangen: een knuffel van mij zal nooit hetzelfde voelen als een knuffel van een dierbare. Ook zal mijn stem nooit hetzelfde klinken. In een verpleeghuis is dat moeilijk op te lossen omdat beeldbellen simpelweg niet voor iedereen is weggelegd. En een raambezoek is best leuk, maar het is natuurlijk geen vervanging van het gevoel van nabijheid en vertrouwen dat lichamelijk contact geeft.'

\section{KLEINE GELUKSMOMENTEN}

Een ander gevolg van de uitbraak van COVID-19 was dat voor thuiswonende mensen met dementie alle vormen van ondersteuning, zoals activiteiten met vrijwilligers, dagbesteding, huishoudelijke hulp en boodschappenhulp, wegvielen. 'Situaties die al pittig waren, werden daardoor nog zwaarder,' zegt Lies. 'Mensen met dementie en hun naasten zaten opeens 24 uur per dag, zeven dagen per week op elkaars lip. Door het wegvallen van vertrouwde structuren raakten mensen met dementie bovendien meer in de war en dat leidde weer tot extra druk op de mantelzorgers. Terwijl het aantal mensen dat over de vloer kwam minimaal was, doordat uit angst voor besmetting zorg en ondersteuning thuis werd afgezegd.'

Toch was er ook een redelijk grote groep die het risico op besmetting voor lief nam, vertelt ze. "Maak het zo comfortabel mogelijk voor me als het zover komt en laat me maar rustig gaan" zeiden ze als ik vroeg wat ze zouden willen, mochten ze besmet raken.' Die eigen regie juicht Lies toe, want hoe je het ook wendt of keert: het gaat om je laatste levensfase. 'Deze mensen hebben hun hele leven hard gewerkt en overleefden in sommige gevallen de Spaanse griep, de Tweede Wereldoorlog én de Watersnoodramp. Moeten ze dan het laatste deel van hun leven opgesloten zitten in hun eigen huis of in een verpleeghuis? Daar mogen ze zelf toch ook iets van vinden?'

Juist de kleine geluksmomenten, zoals een wandeling door het dorp of buiten op een bankje zitten met je zoon of dochter, zijn belangrijk voor mensen met dementie, vindt ook Teun. 'We moeten voorkomen dat wíj gaan bepalen wat belangrijk is voor mensen met dementie. Ook al weet je het antwoord > 


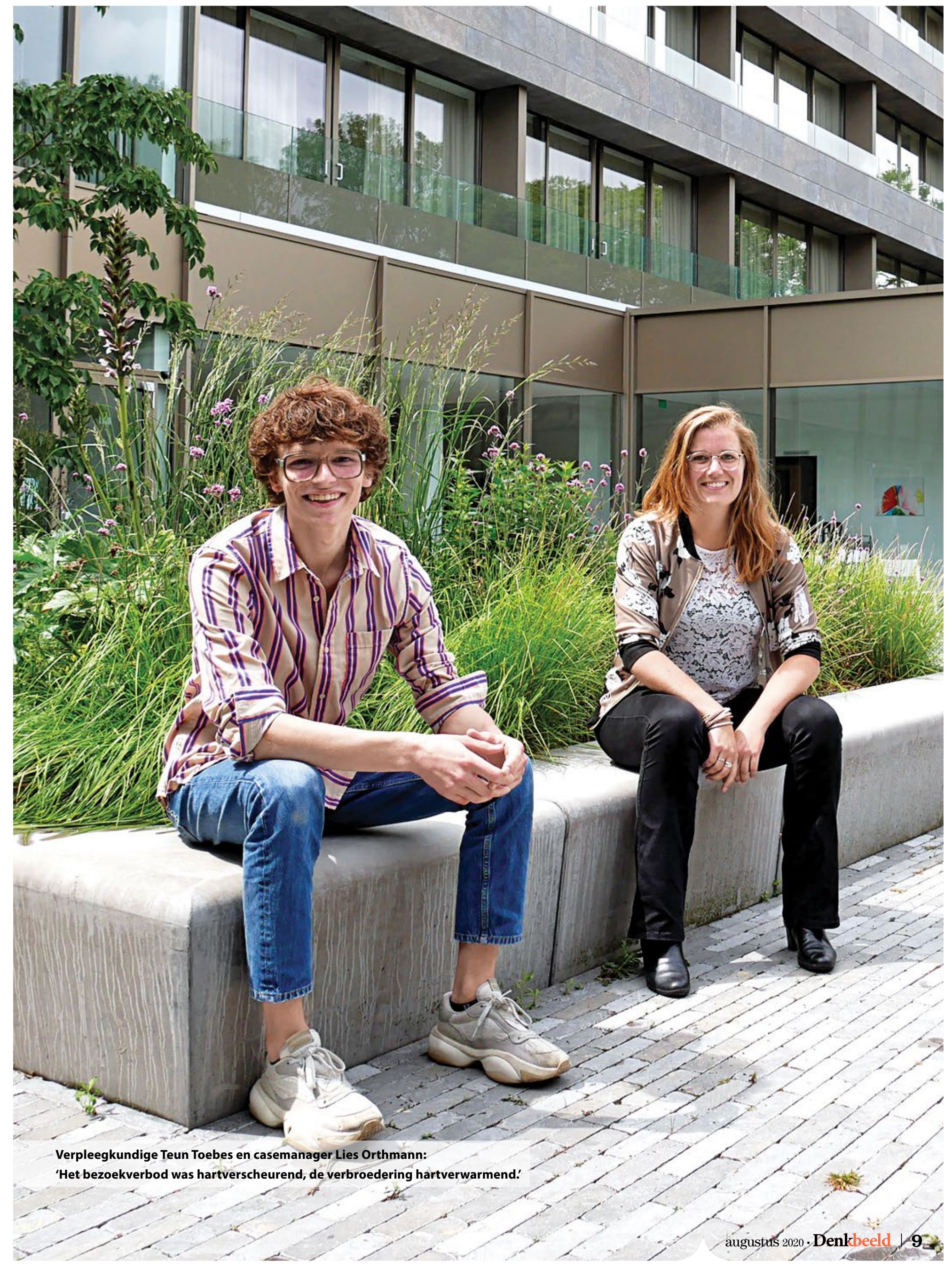


al, je moet de vraag constant blijven stellen. De vrijheid hebben om zelf een antwoord te kunnen bedenken, geeft veel mensen een gevoel van waardigheid.' En is dit niet meer mogelijk, dan heeft de familie een belangrijke stem. 'Laatst hoorde ik over een fantastische actie bij Ouderenlandgoed Grootenhout. Zij vroegen de mantelzorgers of zij wél of géén mondkapje wilden dragen bij het bezoeken van hun geliefde en gaven daarbij een toelichting op de eventuele risico's. Wat denk je? De familieleden stemden unaniem voor bezoek zonder (niet-medisch) mondkapje.'

\section{RUST EN REGELMAAT}

Hier en daar waren er ook positieve effecten merkbaar. 'Bij mensen thuis ontstond soms een weelde van rust,' vertelt Lies. 'Ze hoefden niet langer om zeven uur op te staan om gedoucht te worden of om met het busje naar de dagbesteding te worden gebracht. En mensen die zichzelf vóór de coronacrisis naar de dagbesteding moesten slépen, merkten nu hoe fijn het is om een vaste dagstructuur te hebben. "Ik had nooit gedacht dat ik de dagbesteding zou missen," zeiden ze tegen me. De maatregelen worden dan ook op uiteenlopende manieren beleefd: van alleenstaanden met een actief leven en een groot sociaal netwerk die nu een sociaal isolement ervaren, tot mensen die het wel prima vinden zo omdat ze toch al een vrij afgeschermd leven leidden. Wel is het schrikbarend als je ziet hoe snel sommige mensen achteruit zijn gegaan in twee maanden tijd.' In het verpleeghuis waar Teun werkt, daalde ondanks alles toch een soort rust neer in de woonkamers. 'Soms zorgt de aanwezigheid van familie voor prikkels waarop mensen met dementie blijven reageren. Alles komt natuurlijk uit een goed hart, maar het kan ook wel eens te veel zijn,' zegt hij. Die tegenstelling leidt soms ook tot dubbele gevoelens bij naasten. 'De echtgenoot van een van onze cliënten kwam voorheen elke dag langs om zijn vrouw te helpen met eten. Hij zegt nu: "Het gaat zo goed met haar, is het niet beter voor haar als ik niet meer kom?" Ook de versoepeling van de bezoekregeling leidt weer tot dilemma's, vertelt Teun. 'Vrijwilligers mogen eerder zonder mondkapje met cliënten buiten wandelen dan familieleden mét mondkapje. Dat is natuurlijk moeilijk uit te leggen.'

\section{FOCUS OP KWALITEIT}

'Het was ergens fijn dat de overheid direct houvast bood door maatregelen op te leggen die strikt moesten worden nageleefd, er moest tenslotte snel iets gebeuren,' zegt Lies. 'Maar wel denk ik dat het vrij lang heeft geduurd voor er weer ruimte was voor gesprek en discussie. De deuren van de verpleeghuizen gingen letterlijk op slot en je mocht de politie bellen als familie niet wilde luisteren. Dat is nogal wat.' 'Wij hadden demonstraties voor de deur van het verpleeghuis,' vult Teun aan. 'Beide keren had ik de verantwoordelijke dienst en hing ik de hele dag met de consignatiedienst en de politie aan de lijn. Zonde, want ik besteed mijn tijd liever aan de mensen.' Daar komt nog eens bij dat het aan mensen in een later stadium van dementie moeilijk uit te leggen was waarom er geen bezoek meer mocht komen. Zij begrepen er niets van. Teun: 'De redenering van de overheid was: ouderen vallen binnen een risicogroep, dus die moeten we beschermen. Maar we moeten niet vergeten dat de verpleeghuiszorg ontzettend divers is en er ook jonge mensen met dementie in een verpleeghuis kunnen wonen. Het raakt me enorm dat iemand in zo'n geval geen keuzes meer mag maken over zijn of haar eigen leven. Het was mooi geweest als wij het vertrouwen hadden gekregen om per locatie te bepalen welke maatregelen haalbaar waren, met als uiteindelijke doel zo goed mogelijk te luisteren naar onze cliënten. Niemand kan zo lang zonder een fysieke aanraking van een dierbare. Sommige mensen gaan minder goed eten en vermageren flink.'
Volgens Teun en Lies heeft deze crisis dan ook blootgelegd wat écht belangrijk is in de ouderenzorg: aandacht voor ieders persoonlijke wensen en behoeften. Lies: 'Ik denk dat overheidsingrijpen zeker nodig was, maar dat de afwegingen niet in balans zijn geweest. En zeker in dit stadium van de ziekte zou de discussie wat mij betreft veel meer over kwaliteit van leven moeten gaan.'

\section{HARTVERWARMEND}

Door de coronacrisis staat de zorg meer dan ooit in het middelpunt van de belangstelling. 'Het applaus was mooi, al kwam het wat vroeg. Maar wat er daarna kwam, was nog veel mooier: de immense hoeveelheid kaarten, zelfgebakken taarten en pannenkoeken, spandoeken, krijttekeningen op de stoep en draaiorgels voor de deur,' zegt Lies. Teun: 'Het hele dorp stuurde kaartjes. Als er weer een stapel van twintig of dertig kaarten werd afgeleverd, zag ik pure blijdschap op de gezichten. Sommige mensen konden niet eens lezen wat erop stond, maar dat maakte niet uit. Het gaat om het gevoel dat anderen aan je denken.' Bij mensen met dementie die nog thuis wonen zorgden de maatregelen voor meer eenzaamheid, maar soms was er juist ook sprake van het tegenovergestelde: 'Alleenstaanden ontvingen van wildvreemde kinderen een tekening in de brievenbus, er werden spontane straatconcerten gegeven en buurtgenoten belden aan om te vragen of ze iets konden doen. Ik ken een aantal mensen voor wie dit niet lang genoeg kan duren,' zegt Lies lachend. 'Een mooi voorbeeld: een van mijn cliënten werd negentig jaar, maar kon haar verjaardag niet vieren. Samen met twee medewerkers van haar dagbehandeling en een accordeonist die op dat moment toevallig over straat liep, heb ik onder het balkon uit volle borst voor haar gezongen. Ze heeft de dag van haar leven gehad. Zonder corona hadden we dat waarschijnlijk niet gedaan.' Beide 
zorgprofessionals zouden het mooi vinden als al deze hartverwarmende, lokale initiatieven ook na de crisis blijven bestaan.

\section{MENTALE KLAPPEN}

Toch staan de mooie anekdotes in schril contrast met de vele schrijnende verhalen. Lies vertelt over de vrouw met dementie die haar pols brak, niet begreep waarom haar arm in het gips zat en er thuis alles aan deed om dat gips er af te scheuren, knippen of snijden. 'Haar man belde me in paniek op, dus ik ben direct in de auto gesprongen. Ik had daar wel direct een probleem: de vrouw was zo in de war dat ze die anderhalve meter afstand niet meer begreep. Binnen een mum van tijd waren we te dicht bij elkaar in de buurt geweest. Ik had dit vooraf wel met haar man besproken, maar hij vond het "het risico waard". Binnen een half uur was alles opgelost. Op zo'n moment realiseer je je weer hoe waardevol een casemanager kan zijn. Waar mensen soms dagenlang op vastlopen, heb ik in een half uur opgelost door goed te luisteren en mee te denken. Je moet continu een afweging maken tussen het belang van persoonlijk contact en de veiligheid van de cliënt en jezelf.' Vooral in het begin was de terughoudendheid voor huisbezoeken groot omdat er te weinig beschermende middelen waren, zegt Lies. 'De focus op ziekenhuizen en verpleeghuizen was terecht, maar daarbuiten hadden wij met net zoveel vergelijkbare problemen en dilemma's te maken. En de dood is bij ons ook geen vreemde gast, maar de mate waarin mensen nu stierven had een grote impact, ook op mij als mens. Meerdere cliënten en mantelzorgers die ik soms al jaren had begeleid, werden ziek of kwamen te overlijden. Dit leidde soms tot schrijnende situaties in een tijd dat hulp door alle maatregelen moeilijk te vinden was.'

Lies wijst in dit verband op een citaat van hoogleraar ouderenzorg Marcel Olde Rikkert dat mensen in het laatste sta- dium van hun leven vaak niet zo opzien tegen overlijden, maar zich wel zorgen maken over de manier waarop. 'Mensen willen niet in hun eentje sterven, zonder de hand van hun dierbaren vast te kunnen houden. Maar in de afgelopen maanden is dat op veel momenten onmogelijk geweest. Je ontkwam soms niet aan een gevoel van complete onmacht. Ik maak me zorgen om de klap die voor veel hulpverleners nog gaat komen: we hebben met z'n allen de schouders eronder gezet, maar iedereen heeft mentaal veel te verduren gekregen. En dat krijgen we nog steeds.'

Hoe heeft Teun dat beleefd? 'Familie mocht pas op het allerlaatste moment in het verpleeghuis langskomen om afscheid te nemen. Soms waren ze te laat. De kamers moesten wij leeghalen, waar normaal gesproken de familie dat doet. Het voelt heel onpersoonlijk om een kar met bezittingen van iemand die net is overleden in het magazijn te zetten. Bovendien, inpakken van de bezittingen van een dierbare is onderdeel van rouwen. Dat vindt familie vaak zó waardevol.'

\section{NADER TOT ELKAAR}

Wat doet deze crisis met Lies en Teun als mens? 'Normaal gesproken probeer ik het grijze gebied van de regels en het beleid op te zoeken, maar daar was de afgelopen tijd geen ruimte voor,' zegt Teun. 'Ik vind het moeilijk om mensen niet te kunnen geven wat ze nodig hebben. Op momenten dat het verdriet en het onbegrip groot was, kreeg ik soms tranen in mijn ogen omdat ik ook niet meer wist wat ik moest doen. Soms heerste er een gevoel van onmacht.' Het dragen van mondkapjes, spatbrillen, handschoenen en schorten helpt dan ook niet mee, vooral omdat herkenbaarheid voor mensen met dementie zo belangrijk is. 'Sommige cliënten lachten me uit als ik aan hun bed stond, anderen vonden het heel eng. En voor ons is het verre van ideaal: probeer maar eens iemand te troosten of gerust te stellen met een mondkapje voor, een spatbril op en handschoenen aan. Alles wat vertrouwd voelt voor degene met dementie - je uitstraling, je lach, je stem - verandert of valt weg. Op momenten dat je graag dichtbij wil zijn, wordt er letterlijk afstand gecreëerd. Dat voelt heel onnatuurlijk.'

Ook Lies voelde met name in de eerste anderhalve maand een continue strijd tussen haar eigen onmacht en verdriet en de positieve steun en kracht die ze voor haar cliënten en hun naasten wil zijn. 'Als we ons blindstaren op wat er niet meer kan of wat er niet meer is, komen we in een gevaarlijke neerwaartse spiraal terecht. Als casemanager ga ik altijd uit van wat er nog wél kan. Ik denk dat we ons de komende tijd vooral moeten focussen op hoe we samen het beste van het "nieuwe normaal” kunnen maken.'

Volgens Lies zijn goed luisteren, meedenken en van elkaar leren in die situatie extra belangrijk. 'We voeren veel discussies in de ouderenzorg en zijn het regelmatig met elkaar oneens, terwijl we allemaal hetzelfde doel hebben: een goede kwaliteit van leven voor onze cliënten en hun dierbaren, met aandacht voor hun persoonlijke wensen en behoeften.' Fysiek contact met dierbaren maakt daar in ieder geval onderdeel van uit, zoveel is wel duidelijk geworden in de afgelopen maanden. 'Het bezoekverbod was hartverscheurend, de verbroedering hartverwarmend,' merkt Teun op. Lies kan zich wel vinden in die uitspraak: 'Ik heb het gevoel dat zorgprofessionals door deze crisis nader tot elkaar zijn gekomen.'

TEKST EN BEELD DIEUWKE DE BOER DIEUWKE DE BOER IS FREELANCE JOURNALIST. 